\title{
STUDENTS' PERCEPTIONS OF CLOUD COMPUTING
}

\author{
Chuleeporn Changchit, Texas A\&M University-Corpus Christi, chuleeporn.changchit@tamucc.edu
}

\begin{abstract}
People all over the world are adopting new technologies in order to fulfill their needs. One major benefit of technology nowadays is the ability to process a large amount of data at lightning speeds, which also requires a larger capacity for data storage. Cloud computing has attracted much attention in both commercial and academic settings. This technology can bring an increased number of benefits to an educational setting, not only for its cost effectiveness, but also for the thirst for technology that college students have today, which makes learning and adapting to these new technologies easier for them. This study aims at investigating how cloud computing is perceived by college students and which factors have a tendency to encourage or discourage them to accept the cloud computing as part of their course curriculum.
\end{abstract}

Keywords: Cloud Computing, Technology Acceptance Model (TAM), Perceived Security, Perceived Speed, Perceived Cost, Education

\section{INTRODUCTION}

Technology continues to develop and become a big part of the world each and every day. People all over the world are adopting new technologies in order to fulfill their needs. One major benefit of technology nowadays is the ability to process a large amount of data at lightning speeds, which also requires a larger capacity for data storage. Cloud computing has attracted much attention in both commercial and academic settings. It is estimated that by 2013 , the cloud market will have reached $\$ 8.1$ billion [18]. This computing model has become tremendously popular due to its benefits such as cost-effectiveness, scalability, usefulness, ease of use and worldwide accessibility; although security is still a top concern.

Education is a driving force for the continuous improvement of cloud computing. Students can gain a lot with this model as the technology makes a convenient mobile storage space [23]. Cloud computing can bring an increased number of benefits to an educational setting [7]. It is not only the cost effectiveness, but also the thirst for technology that college students today have, which allows learning and adopting these new technologies easier for them. Cloud computing can be used to students' advantage in an educational setting for completing assignments, online classes, group projects, creating and editing papers and presentations; as well as for work or entertainment. With many benefits yielded by cloud computing models, it is interesting to find out how students perceive this technology. The purpose of this study is to examine the factors that encourage or discourage students to accept cloud computing as part of their course curriculum.

\section{LITERATURE REVIEW}

The cloud computing business model has been around for decades in various forms such as Application Management Services (AMS) and Application Service Providers (ASP). However, due to the higher cost at that time (both for hardware and services), the technology was only feasible as an outsourcing solution to very large organizations who could realize savings based on economies of scale [5]. Although the concept of cloud computing has been around since the beginning of the computing industry in the 1960s, the technology has only recently become robust enough to provide computing services via the Internet [19].

Cloud computing is defined by the National Institute of Standards and Technology (NIST) as a model for enabling ubiquitous, convenient, on-demand network access to a shared pool of configurable computing resources (e.g., networks, servers, storage, applications, and services) that can be rapidly provisioned and released with minimal management effort or service provider interaction [22]. The high demand for more advanced and efficient technology has contributed in the creation of new advancements in technology such as cloud computing. The popularization of cloud computing by companies like Amazon ${ }^{\circledR}$, Google ${ }^{\circledR}$, and Apple ${ }^{\circledR}$ ensure that the usage of the cloud as a storage medium for music, movies, and other media content files, will be ubiquitous in the next 10 years. 


\section{Issues in Information Systems \\ Volume 15, Issue I, pp. 312-322, 2014}

Cloud computing is a promising prospect for educational institutions, especially during budget constraints. Research in cloud computing adoption in the educational settings has focused parts of its efforts to understand the drivers and constrains of students and schools to adopt this computing model. With today's technology, students' learning is no longer confined within the classroom. The educational environment could be improved to allow students to access learning resources anywhere and anytime [31].

One study examined the factors leading to adopting cloud computing as a virtual computing lab for a class [7]. The authors in this study found that students' ease of use perception would positively affect intentions for future use, but not for actual use. Students who complete their work faster and in a more practical manner were more likely to recognize cloud computing as an effective service, and use it more if there is no "effort to learn". This study also found that students with anxiety about new technologies had a negative effect on perceived usefulness. Another study also suggested that in order to deal with technology anxiety, it is important for universities to plan a hands-on training to help students become more familiar with these new technologies [8].

The benefits and risks of migrating to a cloud are frequently discussed in business literature. The best feature of cloud computing is the scalability that allows computing loads to be more balanced even as the number of users increases, while also realizing economies of scale [19]. Firms in both public and private sectors are constantly faced with the challenges of maintaining enterprise architecture that serves the functionality of the business, while also contending with wide ranges of end user demands.

There are many benefits recognized when changing to cloud computing, among the most common is low cost [12, 15]. Cloud computing is cost effective and sometimes, it can even be free. This all depends on the services needed. The costs of IT are reduced because there is no installing, maintaining, or updating software as well as the prevention of IT emergencies or working after hours $[12,24]$. Cost savings also include equipment, as there is no need for expensive computers with large capacity storage, expensive hard drives, RAMs, or operating systems [4, 24]. In addition, there is no need for a physical space to store equipment [24] or for infrastructure facilities [23]. These attributes will also be beneficial for data safety. Since all data is stored miles away, the data will be secure in case of a natural disaster, or in the face of any other possible threats [15]. With many benefits promised by the use of cloud computing, it is not surprising that the demand for graduates with exposure to Cloud Computing is on the rise [11]. However, before integrating such topics into the curriculum, it is crucial to understand which factors can encourage or discourage students from accepting it as a part of their course curriculum. The findings in this study should help programs to focus on the factors that encourage students to like the topic as well as finding ways to minimize the effect of discouraging factors, thus increasing the chance for the success of the cloud computing program integration.

\section{RESEARCH MODEL AND HYPOTHESES}

The Technology Acceptance Model (TAM) developed by Davis was proposed in 1986 to address the question why users accept or reject information technology. The model was derived from the Theory of Reasoned Action, developed by Fishbein and Ajzen (1975). TAM was a big hit for modeling user acceptance of information systems $[6,13]$. It has stood the test of time by being the leading model for nearly two decades. TAM is considered the most influential and commonly employed theory for describing an individual's acceptance of information systems [17].

This study has modified the Technology Acceptance Model to include three additional factors: (1) Perceived Security (PS), (2) Perceived Speed of Access (PSA), and (3) Perceived Cost of Usage (PCU). The proposed research model is shown in Figure 2 below.

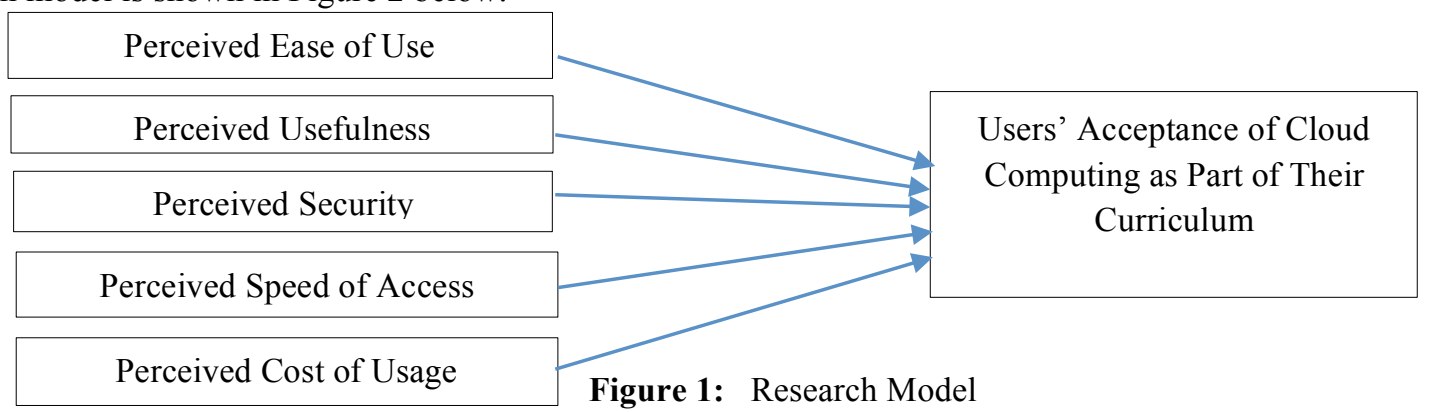




\section{Issues in Information Systems \\ Volume 15, Issue I, pp. 312-322, 2014}

Perceived usefulness is defined as the prospective users' subjective probability that using a specific application system will increase his or her job performance within an organizational context [13]. This factor has a significant effect on usage intention $[3,13,25,26]$. Perceived ease of use is defined as the degree to which the prospective user expects the target system to be free of effort [13]. This factor plays a crucial role in understanding individual responses to information technology $[1,10,16]$. Research over the past decade provides evidence of the significant effect perceived ease of use has had on usage intention $[3,25,26]$.

Security usually refers to the degree of protection against loss, damage, danger, and criminal activity. Having a security awareness is an important issue for all individuals who are dealing with sensitive data in everyday life [9]. Security has been studied and defined in several prior studies. For instance, Yenisey et al. [32] defined perceived security in E-commerce as the level of security that users feel while they are shopping online. Flavián and Guinalíu, (2006) presented their view of perceived security as a subjective probability with which consumers believe that their personal information (private and monetary) will not be viewed, stored, and manipulated during transit and storage by inappropriate parties in a manner consistent with their confident expectations. Roca et al. (2009) defined overall perceived security as a threat that creates a circumstance, condition, or event with the potential to cause economic hardship to data or network resources in the form of destruction, disclosures, modification of data, denial of service, and/or fraud, waste and abuse.

The speed of using applications over the Internet can be a factor that has prevented cloud computing from being a viable option for outsourcing IT operations. Users may be unaware that the use of applications via the Internet still allows them to retrieve the data at the same speed as when the data is stored in their personal computers. For cloud computing to be widely accepted, it is crucial that the services must allow users to access data at a reasonable speed. Users' perception towards the speed of access should influence their intention to use the cloud computing service. A survey conducted by ComputerWorld magazine [30] of IT professionals revealed that while "saves money" ranked first on the list of cloud computing key benefits, "costs more" ranked third on the list of drawbacks suggesting that the issue of cost in outsourcing information technology resources is a complex issue. In many public and private sector industries, including education, federal and state government, and telecommunications, cloud computing systems are being pilot-tested and implemented to save IT costs and improve performance [7].

Relating to all factors discussed above, the following are the hypotheses for testing the relationship among these factors as proposed in the research model.

- H1: There is a significant difference on the perceptions about the Perceived Usefulness (PU) between the subjects who believe that cloud computing should be part of their curriculum and those who do not.

- H2: There is a significant difference on the perceptions about the Perceived Ease of Use (PEU) between the subjects who believe that cloud computing should be part of their curriculum and those who do not.

- H3: There is a significant difference on the perceptions about the Perceived Security (PS) between the subjects who believe that cloud computing should be part of their curriculum and those who do not.

- H4: There is a significant difference on the perceptions about the Perceived Speed of Access (PSA) between the subjects who believe that cloud computing should be part of their curriculum and those who do not.

- H5: There is a significant difference on the perceptions about the Perceived Cost of Usage (PCU) between the subjects who believe that cloud computing should be part of their curriculum and those who do not.

\section{RESEARCH METHODOLOGY}

The questionnaire designed for this study adapted the instrument and scales developed from TAM with additional constructs as described in the proposed research model [26]. The questions used to measure the Perceived Security constructed were adapted from prior studies [20, 26, 28, 29]. The questionnaire consists of thirty-three questions. Twenty-five questions with the five point Likert scale were designed to measure subjects' perceptions on cloud computing. One question (Question\# 26) asks whether subjects believe that cloud computing should be a topic which should be offered as a university core course. The remaining seven questions were asked to gather some demographic data of the subjects. To validate the clarity of these questions, three professors and three researchers were asked to read through the survey questions. Revisions to the survey were made based on the feedback received. The questionnaire is presented in the Appendix at the end of this paper. The surveys were administered to students at a Southern United States University. Five hundred and eighty-five (585) subjects participated in this 
study. However, only five hundred and fifty-eight (558) responses are valid. Details on the subjects' demographics are provided in Table 1 below.

Table 1. Subjects' Demographics

\begin{tabular}{|c|c|c|c|c|c|c|c|c|c|c|c|c|c|}
\hline \multicolumn{14}{|l|}{ Gender } \\
\hline \multicolumn{3}{|c|}{ Male: $285(51.1 \%)$} & \multicolumn{6}{|c|}{ Female: $262(47 \%)$} & \multicolumn{5}{|c|}{ No Answer: 11 (1.9\%) } \\
\hline \multicolumn{14}{|c|}{ First generation college student (if student) } \\
\hline \multicolumn{3}{|c|}{ Yes: $198(35.5 \%)$} & \multicolumn{6}{|c|}{ No: $310(55.6 \%)$} & \multicolumn{5}{|c|}{ No answer: $49(8.8 \%)$} \\
\hline \multicolumn{14}{|c|}{ Age (in years) } \\
\hline \multicolumn{2}{|c|}{ 18-24: $449(80.5 \%)$} & \multicolumn{3}{|c|}{ 25-34: $76(13.6 \%)$} & \multicolumn{3}{|c|}{ 35-44: $14(2.5 \%)$} & \multicolumn{4}{|c|}{45 and over: $9(1.6 \%)$} & \multicolumn{2}{|c|}{ No Answer: $10(1.8 \%)$} \\
\hline \multicolumn{14}{|l|}{ Ethnicity } \\
\hline $\begin{array}{l}\text { African: } \\
18(3.2 \%)\end{array}$ & \multicolumn{2}{|c|}{$\begin{array}{l}\text { Anglo: } \\
209(37.5 \%)\end{array}$} & \multicolumn{2}{|c|}{$\begin{array}{l}\text { Asian: } \\
57(10.2 \%)\end{array}$} & \multicolumn{3}{|c|}{$\begin{array}{l}\text { Hispanic: } \\
207(37.1 \%)\end{array}$} & \multicolumn{3}{|c|}{$\begin{array}{l}\text { Native American: } \\
4(0.7 \%)\end{array}$} & \multicolumn{2}{|c|}{$\begin{array}{l}\text { Other: } \\
27(4.8 \%)\end{array}$} & $\begin{array}{l}\text { No Answer: } \\
36(6.5 \%)\end{array}$ \\
\hline \multicolumn{14}{|l|}{ College } \\
\hline \multicolumn{2}{|l|}{$\begin{array}{l}\text { Business: } \\
300(53.8 \%)\end{array}$} & \multicolumn{2}{|c|}{$\begin{array}{l}\text { Education: } \\
20(3.6 \%)\end{array}$} & \multicolumn{2}{|c|}{$\begin{array}{l}\text { Liberal Art: } \\
64(11.5 \%)\end{array}$} & \multicolumn{3}{|c|}{$\begin{array}{l}\text { Nursing: } \\
29(5.2 \%)\end{array}$} & \multicolumn{4}{|c|}{$\begin{array}{l}\text { Science \& Technology: } \\
126(22.6 \%)\end{array}$} & $\begin{array}{l}\text { No Answer: } \\
19(3.4 \%)\end{array}$ \\
\hline \multicolumn{14}{|c|}{ Classification (if student) } \\
\hline \multicolumn{2}{|l|}{$\begin{array}{l}\text { Freshman: } \\
136(24.4 \%)\end{array}$} & \multicolumn{3}{|c|}{$\begin{array}{l}\text { Sophomore: } \\
140(25.1 \%)\end{array}$} & \multicolumn{2}{|c|}{$\begin{array}{l}\text { Junior: } \\
167(29.9 \%)\end{array}$} & \multicolumn{3}{|c|}{$\begin{array}{l}\text { Senior: } \\
66(11.8 \%)\end{array}$} & \multicolumn{3}{|c|}{$\begin{array}{l}\text { Graduate: } 31 \\
(5.6 \%)\end{array}$} & $\begin{array}{l}\text { Other: } \\
18(3.2 \%)\end{array}$ \\
\hline \multicolumn{14}{|c|}{ Employment Status } \\
\hline \multicolumn{3}{|c|}{ Full- time: $78(14.0 \%)$} & \multicolumn{4}{|c|}{ Part-time: $249(44.6 \%)$} & Une & emp & loyed: 2 & $3(39$ & $1 \%)$ & No & nswer: $13(2.3 \%)$ \\
\hline
\end{tabular}

\section{DATA ANALYSIS AND DISCUSSION}

In order to examine the internal consistency of the research instrument, a reliability test was conducted. The test confirmed the reliability of the research items with Cronbach's alpha coefficient of 0.921 . To determine if there were significant differences regarding the factors between the groups of subjects who believe that cloud computing should be part of their curriculum and those who do not, t-tests on the means were conducted. The responses from subjects were divided into two groups (Cloud Computing" and "Non-Cloud Computing") based on their responses to the survey item Q26 - "I believe that cloud computing should be a topic which should be offered as a university core course".

Of all the five hundred and fifty-eight (558) subjects, one hundred and ninety-eight (198) believe that the cloud computing should be offered as a university core course, those who responded with a 4 or a 5 . One hundred and fifty-six (156) do not agree that cloud computing should be offered as a university core course, those who responded with a 1 or a 2 . The subjects who were uncertain on this issue (204 subjects), those who did not answer or responded with a 3, were excluded from the data analysis. The t-tests were performed to examine if there is a significant difference on the perceptions of subjects on the five factors investigated in the research model. Tables 26 shows the result of t-test on the five factors investigated in this study. 


\section{Table 2. Perceived Usefulness}

\begin{tabular}{|l|r|r|}
\hline $\mathrm{t}$-Test: Two-Sample Assuming Unequal Variances & & \\
\hline \multicolumn{1}{|c|}{ Perceived Usefulness } & & \\
\hline Mean & Non-Cloud Computing & Cloud Computing \\
\hline Variance & 3.387179487 & 4.065656566 \\
\hline Observations & 0.899963606 & 0.432012511 \\
\hline Hypothesized Mean Difference & 156 & 198 \\
\hline $\mathrm{df}$ & 0 & \\
\hline $\mathrm{t}$ Stat & 265 & \\
\hline $\mathrm{P}(\mathrm{T}<=\mathrm{t})$ one-tail & -7.609000494 & \\
\hline $\mathrm{t}$ Critical one-tail & $2.42129 \mathrm{E}-13$ & \\
\hline $\mathrm{P}(\mathrm{T}<=\mathrm{t})$ two-tail & 1.650623976 & \\
\hline $\mathrm{t}$ Critical two-tail & $4.84257 \mathrm{E}-13$ & \\
\hline
\end{tabular}

Regarding hypothesis $\mathrm{H} 1$, the results in Table 2 above show a significant difference on the perceived usefulness between subjects in the two groups at a p-value $<0.01$. This finding indicates that subjects who perceive usefulness of the cloud computing as high are likely to accept the cloud computing as part of their core curriculum. Students nowadays tend to live with an idea that learning should occur at their convenience. Therefore, the higher level of usefulness they perceive in using cloud computing, the more likely that they are willing to learn more about this technology.

Table 3. Perceived Ease of Use

\begin{tabular}{|l|r|r|}
\hline \multicolumn{1}{|c|}{ Perceived Ease of Use } & & \\
\hline & & \\
\hline Mean & Non-Cloud Computing & Cloud Computing \\
\hline Variance & 3.103205128 & 3.692929293 \\
\hline Observations & 0.811021919 & 0.522081731 \\
\hline Hypothesized Mean Difference & 156 & 198 \\
\hline $\mathrm{df}$ & 0 & \\
\hline $\mathrm{t}$ Stat & 293 & \\
\hline $\mathrm{P}(\mathrm{T}<=\mathrm{t})$ one-tail & -6.662110453 & \\
\hline $\mathrm{t}$ Critical one-tail & $6.67189 \mathrm{E}-11$ & \\
\hline $\mathrm{P}(\mathrm{T}<=t)$ two-tail & 1.650070786 & \\
\hline $\mathrm{t}$ Critical two-tail & $1.33438 \mathrm{E}-10$ & \\
\hline
\end{tabular}

Concerning hypothesis $\mathrm{H} 2$, the results in Table 3 above show a significant difference on the perceived ease of use between subjects in the two groups at the p-value $<0.01$. This finding points out that subjects tend to accept the cloud computing as part of their core curriculum if they perceive that the technology of cloud computing is not difficult to use. The result conforms to a prior study that students intend to recognize cloud computing as an effective service if there is no additional effort to learn. 
Table 4. Perceived Security

\begin{tabular}{|l|r|r|}
\hline \multicolumn{1}{|c|}{ Perceived Security } & & \\
\hline & & \\
\hline Mean & Non-Cloud Computing & Cloud Computing \\
\hline Variance & 3.088461538 & 3.702020202 \\
\hline Observations & 0.894575682 & 0.759285238 \\
\hline Hypothesized Mean Difference & 156 & 198 \\
\hline $\mathrm{df}$ & 0 & \\
\hline $\mathrm{t}$ Stat & 319 & \\
\hline $\mathrm{P}(\mathrm{T}<=\mathrm{t})$ one-tail & -6.272165631 & \\
\hline $\mathrm{t}$ Critical one-tail & $5.78832 \mathrm{E}-10$ & \\
\hline $\mathrm{P}(\mathrm{T}<=\mathrm{t})$ two-tail & 1.649644319 & \\
\hline $\mathrm{t}$ Critical two-tail & $1.15766 \mathrm{E}-09$ & \\
\hline
\end{tabular}

For hypothesis $\mathrm{H} 3$, the results in the Table 4 above also shows a significant difference between subjects in the two groups at the p-value $<0.01$. Security is always a major concern when people have to deal with technology. Subjects who are willing to store their data in the cloud storage tend to believe that their data will be secure. It is not surprising that the perception on the security of cloud computing should play an important role in whether subjects will like to learn about this topic or not. Subjects who view this technology as secured storage tend to want to learn more about this technology and agree that it should be integrated as part of their curriculum.

Table 5. Perceived Speed of Access

\begin{tabular}{|l|r|r|}
\hline $\mathrm{t}$-Test: Two-Sample Assuming Unequal Variances & & \\
\hline \multicolumn{1}{|c|}{ Perceived Speed of Access } & & \\
\hline Mean & Non-Cloud Computing & Cloud Computing \\
\hline Variance & 3.300641026 & 3.791414141 \\
\hline Observations & 0.848451199 & 0.412971594 \\
\hline Hypothesized Mean Difference & 156 & 198 \\
\hline $\mathrm{df}$ & 0 & \\
\hline $\mathrm{t}$ Stat & 266 & \\
\hline $\mathrm{P}(\mathrm{T}<=\mathrm{t})$ one-tail & -5.657724564 & \\
\hline $\mathrm{t}$ Critical one-tail & $1.97952 \mathrm{E}-08$ & \\
\hline $\mathrm{P}(\mathrm{T}<=\mathrm{t})$ two-tail & 1.650602207 & \\
\hline $\mathrm{t}$ Critical two-tail & $3.95904 \mathrm{E}-08$ & \\
\hline
\end{tabular}

Regarding hypothesis $\mathrm{H} 4$, the results in Table 5 above also shows a significant difference between subjects in the two groups at the $p$-value $<0.01$. It is pretty obvious that the speed of access should be considered a crucial feature of cloud computing. Subjects who view cloud computing as having a good speed of access are more likely to accept the cloud computing as part of their core curriculum. 
Table 6. Perceived Cost of Usage

\begin{tabular}{|l|r|r|}
\hline $\mathrm{t}$-Test: Two-Sample Assuming Unequal Variances & & \\
\hline \multicolumn{1}{|c|}{ Perceived Cost of Usage } & & Cloud Computing \\
\hline Mean & Non-Cloud Computing & 3.582575758 \\
\hline Variance & 0.525591708 & 0.403869982 \\
\hline Observations & 156 & 198 \\
\hline Hypothesized Mean Difference & 0 & \\
\hline $\mathrm{df}$ & 310 & \\
\hline $\mathrm{t}$ Stat & -8.29174083 & \\
\hline $\mathrm{P}(\mathrm{T}<=\mathrm{t})$ one-tail & $1.71879 \mathrm{E}-15$ & \\
\hline $\mathrm{t}$ Critical one-tail & 1.649783823 & \\
\hline $\mathrm{P}(\mathrm{T}<=\mathrm{t})$ two-tail & $3.43757 \mathrm{E}-15$ & \\
\hline $\mathrm{t}$ Critical two-tail & 1.967645929 & \\
\hline
\end{tabular}

For hypothesis H5, the results in Table 6 above also show a significant difference on the perceived cost of usage between subjects in the two groups at the $\mathrm{p}$-value $<0.01$. This finding indicates that subjects who perceive the cost of the cloud computing as low are willing to learn more about the cloud computing technology and are likely to accept it as part of their core curriculum.

\section{CONCLUSIONS}

Cloud computing is an emerging technology which promises to provide opportunities for delivering a variety of computing services in a way that has not been experienced before. It is predicted that this technology will continue to grow both in the public and private sectors. In order to increase competiveness of students in the job market, it is the responsibility of educational institutions to ensure that their students are equipped with knowledge of this highly demanded technology. However, to ensure the success of program delivery, it is crucial for the universities to examine which factors play an important role in influencing students to accept cloud computing as part of their curriculum.

The results in this study reveal that all five factors, perceived usefulness, perceived ease of use, perceived security, perceive speed of access, and perceived cost of usage are factors that play an important role in encouraging students to accept cloud computing as part of their core curriculum. For the factor "perceived usefulness," it is very clear from the result that if students perceive cloud computing as a technology that will be beneficial to them, they will be generally open to using it as well as learning it as part of their curriculum.

Since college students today grew up with the computers that are all around them, in their homes and schools, they have experienced everything from the "old fashioned" large desktop to the latest phone with all computing capabilities and yet small enough to fit in their pocket. Although those students may not actually understand the real technology behind the screen, they tend to be more likely to accept cloud computing if their "perceived ease of use" is high, which means that less effort is required to learn how to use it.

Although many students tend to trust the services rendered by their universities simply because they do not feel that their college would provide a service that is unsafe, not all students feel secure to store confidential data on someone else's storage. The result in this study reveals that students will be more likely to accept cloud computing technology and are willing to learn about it if they perceive this technology as a secure mean to store their data. It is apparent that students do not want to be forced to use any technology that is not considered safe and secure. This finding suggests that it may be worthwhile for the universities to educate students about the security of cloud computing before introducing it as part of their core curriculum.

The speed of access to cloud storage is also a crucial factor in this study. Students prefer technology that allows them to get the thing they want in a timely manner. They do not want to deal with multiple pages waiting to download. Therefore, it is not surprising to find that the students who perceive a higher speed of access in cloud computing are more likely to accept it and are willing to accept it as part of their curriculum. 


\section{Issues in Information Systems \\ Volume 15, Issue I, pp. 312-322, 2014}

The cost of using new technology is always a major concern for everyone. It does not matter how great a service a new technology can render, it will be useless if the costs are higher than the benefits. The result in this study points out that students will be more likely to accept cloud computing technology if they perceive that it does not cost them much to use the technology.

There is an inherent limitation in this paper. The sample in this research was limited to subjects in one university and the majority of respondents (53.8\%) were from one college. Although there was an attempt to gather the data from a variety of courses in the university, future research should be conducted at multiple colleges and universities. Further research should also consider expanding demographics to include users in various countries. In addition, a future study could investigate in more detail which feature of cloud computing helps increase students' effectiveness and efficiency in the classroom.

\section{REFERENCES}

1. Agarwal, R., \& Karahanna, E. (2000). Time flies when you're having fun: cognitive absorption and beliefs about information technology usage. MIS Quarterly, 24, 665-694.

2. Agarwal, R. \& Prasad, J. (1997). The role of innovation characteristics and perceived voluntaries in the acceptance of information technologies. Decision Sciences, 28, 557-582.

3. Agarwal, R. \& Prasad, J. (1999). Are individual differences germane to the acceptance of information technologies? Decision Sciences, 30, 361-391.

4. Aljabre, A. (2012). Cloud computing for increased business value. International Journal of Business and Social Science, 3, 234-239.

5. Altaf, F. \& Schuff, D. (2010). Taking a flexible approach to ASPs. Communications of the ACM, 53(2), 139143.

6. Bagozzi, R.P. (2007). The legacy of the Technology Acceptance Model and a proposal for a paradigm shift. Journal of the Association for Information Systems, 8, 244-254.

7. Behrend, T., Wiebe, E.N., London, J., \& Johnson, E. (2011). Cloud computing adoption and usage in community colleges. Behavior \& Information Technology, 30(2), 231-240.

8. Blue, E., \& Tirotta, R. (2011). The benefits and drawbacks of integrating cloud computing and interactive whiteboards in teacher preparation. TechTrends, 55, 31-39.

9. Changchit, C. (2008). Data protection and privacy issue. Journal of Information Privacy and Security, 1.

10. Chau, P.Y.K., \& Hu, P.J.H. (2001). Information technology acceptance by individual professionals: a model comparison approach. Decision Sciences, 32, 699-719.

11. Chen, L., Liu, Y., Gallagher, M., Pailthorpe, B., Sadiq, S., Shen, H. T., Li, X. (2012). Introducing cloud computing topics in curricula. Journal of Information Systems Education, 23(3), 315-324.

12. Das, P., Classen, H. W., \& Dave, R. (2013). Cyber-Security threats and privacy controls for cloud computing, emphasizing software as a service. The Computer \& Internet Lawyer, 30, 20-24.

13. Davis, F.D., Bagozzi, R.P., \& Warshaw, P.R. (1989). User acceptance of computer technology: a comparison of two theoretical models. Management Science, 35, 982-1003.

14. Flavian, C., \& Guinaliu, M. (2006). Consumer trust, perceived security and privacy policy: three basic elements of loyalty to a web site. Industrial Management \& Data Systems, 106, 601-620.

15. Han, Y. (2010). On the Clouds: A new way of computing. Information Technology and Libraries, 87-92.

16. Hong, W., Thing, J., Wong, W., \& Tam, K.Y. (2001). Determinants of user acceptance of digital libraries: an empirical examination of individual differences and system characteristics. Journal of Management Information Systems, 18, 97-125.

17. Lee, Y., Kozar, K.A., \& Larsen, K.R.T. (2003). The Technology Acceptance Model: past, present, and future. Communications of the Association for Information Systems, 12, 752-780.

18. Lin, A., \& Chen, N. (2012). Cloud computing as an innovation: perception, attitude, and adoption. International Journal of Information Management, 1-8.

19. Marston, S., Li, Z., Bandyopadhyay, S., Zhang, J., \& Ghalsasi, A. (2011). Cloud computing - the business perspective. Decision Support Systems, 51, 176-189.

20. Pikkarainen, T., Pikkarainen, K., Karjaluoto, H., \& Pahnila, S. (2004). Consumer acceptance of online banking: an extension of the Technology Acceptance Model. Internet Research, 14, 224-235.

21. Roca, J.C., Garcia, J.J., \& De La Vega, J.J. (2009). The importance of perceived trust, security, and privacy in online trading systems. Information Management and Computer Security, 17, 96-113. 


\section{Issues in Information Systems \\ Volume 15, Issue I, pp. 312-322, 2014}

22. Santalesa, R. (2011). Definition of cloud computing - NIST releases final SP 800-145. Retrieved from http://www.infolawgroup.com/2011/10/articles/cloud-computing-1/definition-of-cloud-computing-nist-releasesfinal-sp-800145/

23. Singh, S.P, \& Veralakshmi, R.S.R. (2012). Cloud computing: A promising economic model for library and information centers. DESIDOC Journal OF Library \& Information Technology, 32, 526-532.

24. Susanto, H., Almunawar, M. N., \& Kang, C. C. (2012). Toward cloud computing evolution: efficiency vs. trendy vs. security. Computer Science Journal.

25. Venkatesh, V. (2000). Determinants of perceived ease of use: integrating control, intrinsic motivation, and emotion into the Technology Acceptance Model. Information Systems Research, 11, 342-365.

26. Venkatesh, V., \& Davis, F.D. (2000). "A theoretical extension of the technology acceptance model: four longitudinal field studies. Management Science, 46(2), 186-204.

27. Venkatesh, V., Morris, M.G., Davis, G.B. \& Davis, F.D. (2003). User acceptance of information technology: toward a unified view. MIS Quarterly, 27, 425-478.

28. Vijayasarathy, L.R. (2004). Predicting consumer intentions to use on-line shopping: the case for an augmented Technology Acceptance Model. Information and Management, 41, 747-762.

29. Wong, Y.K. and Hsu, C.J., (2008). A confidence-based framework for business to consumer (B2C) mobile commerce adoption. Personal and Ubiquitous Computing, 12(1), 77-84.

30. Wood, L. (2011). Cloud storage a steep climb. ComputerWorld, 20-30.

31. Wu, C. (2013). Learning attitude and its effect on applying cloud computing service to it education. International Journal of $u$ - and e-Service, Science and Technology, 6(1), 39-48.

32. Yesisey, M., Ozok, A., \& Salvendy, G. (2005). Perceived security determinants in E-commerce among Turkish university students. Behavior \& Information Technology, 24, 259-274. 


\section{APPENDIX \\ CLOUD COMPUTING QUESTIONNAIRE}

For the purpose of this study, cloud computing is defined as "a technology model in which any and all resourcesapplication software, processing power, data storage, backup facilities, development tools... literally everything-are delivered as a set of services via the Internet" (Aljabre, 2012).

For the following statements, please circle the answer that best represents your opinion.

1--- strongly disagree $\quad 2$--- disagree $\quad 3$--- uncertain $\quad 4$--- agree $\quad 5$--- strongly agree

I believe that using cloud computing...

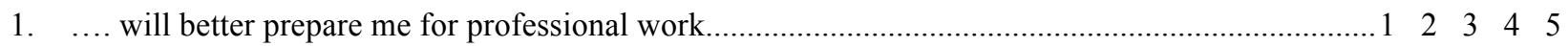

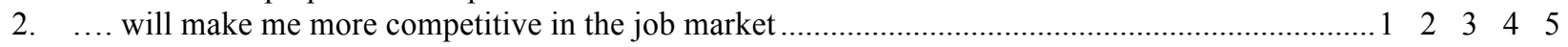

3. .... will make me more efficient performing computer tasks....................................................... $1 \begin{array}{lllll}2 & 3 & 4 & 5\end{array}$

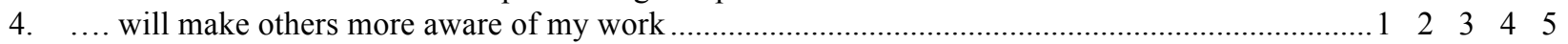

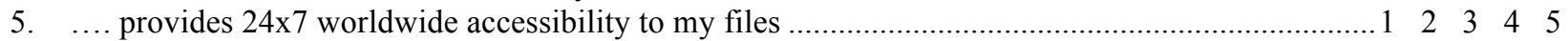

I believe that it is easy to ...

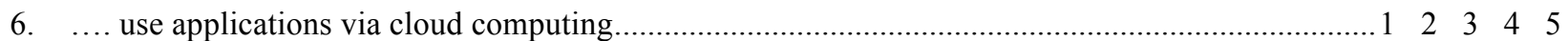

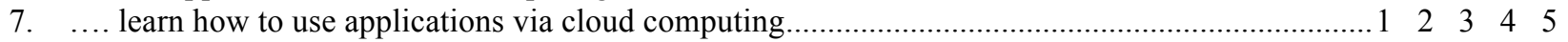

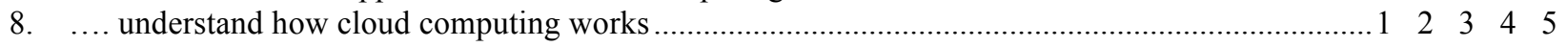

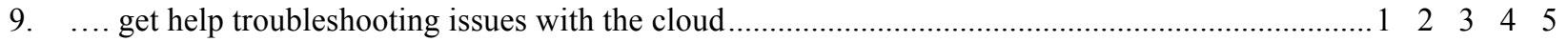

10. .... find vendors that offer cloud computing services .................................................................. $1 \begin{array}{lllll}2 & 2 & 3 & 4 & 5\end{array}$

I believe that by using cloud computing, the company that provides the service will ...

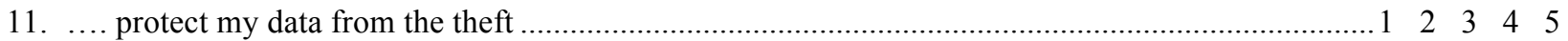

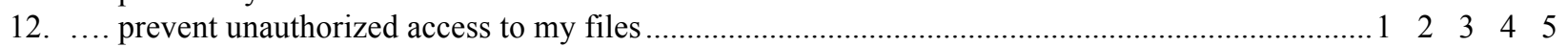

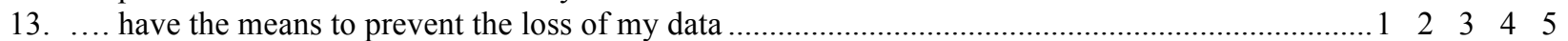

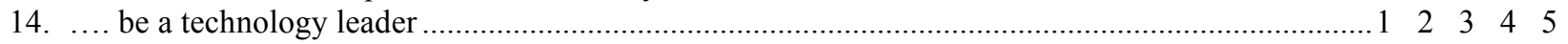

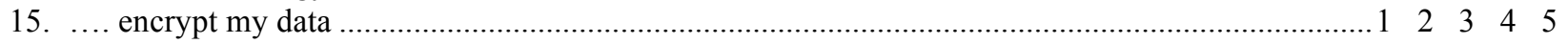

I believe that the speed of cloud computing ...

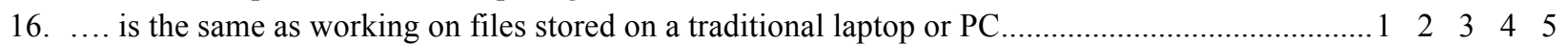

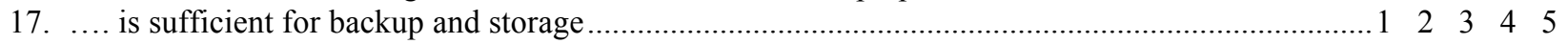

18. .... to upload/download files is the same as uploading/downloading to any other Internet website... $1 \begin{array}{lllll}2 & 2 & 3 & 4 & 5\end{array}$

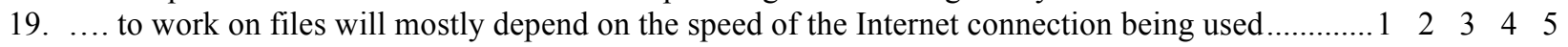

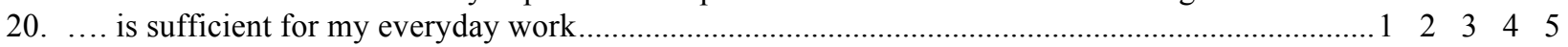

I believe that the cost of cloud computing is ....

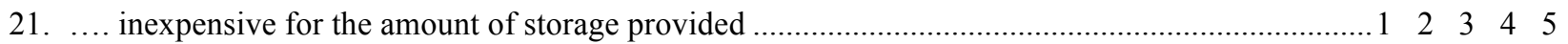

22. .... less expensive than buying software applications for a laptop/PC......................................... $1 \begin{array}{lllll}2 & 2 & 4 & 4\end{array}$

23. .... is expensive compared to cost of using open source or Internet applications .............................1 $2 \begin{array}{llll}2 & 3 & 4 & 5\end{array}$

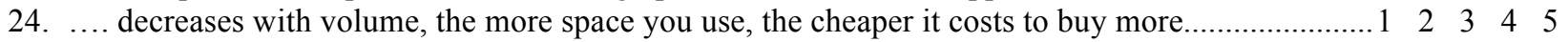

25. .... inexpensive considering the cost of maintenance I have to spend if I use my own storage.......... $1 \begin{array}{lllll}1 & 2 & 3 & 4 & 5\end{array}$

I believe cloud computing is a topic ....

26. .... which should be offered as an university core course......

Please answer the following questions.

27. Do you own a computer/laptop? A. Yes B. No 
28. Do you have Internet access at home? A. Yes B. No

29. If employed, do you have Internet access at work? A. Yes B. No

30. How would you rate yourself with respect to your knowledge about how computer storage works?

$$
\begin{array}{lllllll}
1 \text { (very poor) } & 2 & 3 & 4 & 5 & 6 & 7 \text { (excellent) }
\end{array}
$$

31. Prior to this survey, had you heard of cloud computing? A. Yes B. No
a. If Yes, do you use cloud computing? A. Yes B. No
b. If Yes, how often do you use cloud computing?
A. more than once a day
B. 1-7 times/week
C. 1-3 times/month
D. less than once a month

32. Do you use a USB/flash drive to store or backup files? A. Yes B. No

33. Do you use an Internet service to backup files online? A. Yes B. No

a. If Yes, how often do you use an internet backup service to store files?
A. more than once a day
B. 1-7 times/week
C. 1-3 times/month
D. less than once a month

34. What is your current employment status?
A. Full-time
B. Part-time
C. Unemployed

a. If employed, does your current job require the use of cloud computing? A. Yes B. No

b. If employed, your annual income is:
A. under $\$ 20,000$
B. $\$ 20,001-\$ 40,000$
C. $\$ 40,001-\$ 60,000$
D. $\$ 60,001$ and over

c. If employed, have you worked prior to your current employment? A. Yes B. No

i. If Yes, did your previous work require the use of cloud computing? A. Yes B. No

35. Your gender: A. Male B. Female

36. Your age:

A. $18-24$

B. $25-34$

C. $35-44$

D. 45 and over

37. Your ethnicity: A. African
B. Anglo
C. Asian
D. Hispanic
E. Native American
F. Other

38. Your status: A. Student $\quad$ B. Faculty C. Staff(non-student)

a. If Student, what is your classification?

$\begin{array}{llll}\text { A. Freshman } & \text { B. Sophomore C. Junior } & \text { D. Senior E. Graduate }\end{array}$

b. If Student, are you a first generation college student? A. Yes B. No

c. If Student, how do you financially support your education? (Mark all that apply)
A. Self B. Parents C. Spouse
H. Employer I. Other
D. Children E. Scholarship F. Financial Aid
G. Loan

39. Your college:

A. Business

B. Education

C. Liberal Art

D. Nursing

E. Science \& Technology 